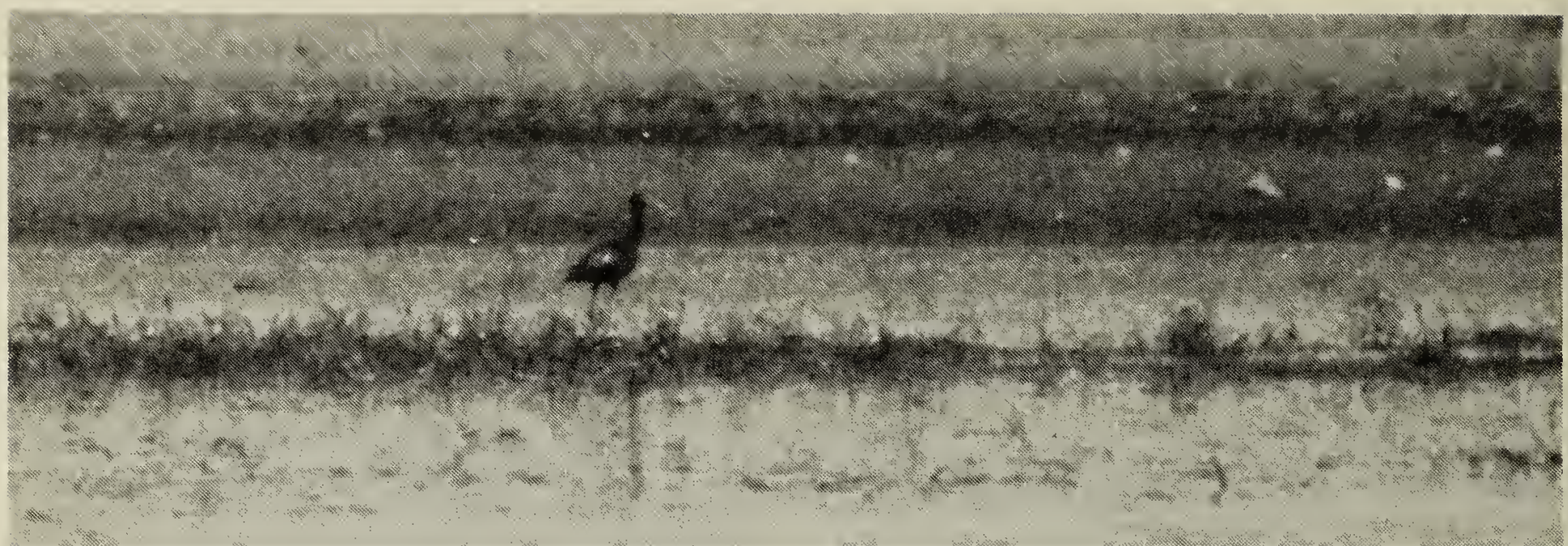

White-faced Ibis, Last Mountain Lake. May 30, 1976.

Fred Lahrman

\title{
WHITE-FACED IBIS \\ IN SASKATCHEWAN
}

FRED W. LAHRMAN, Saskatchewan Museum of Natural History, Regina, Sask.

On May 29, 1976, Mr. Bob Luterbach reported seeing a White-faced Ibis (Plegadis chihi) approximately 6 miles east of Stalwart near Last Mountain Lake. I believe that this constitutes the first sight record of this species for Saskatchewan.

Bob was observing a large flock of approximately 500 Red Knots and other shore birds when the ibis appeared.

On the following day Bob Luterbach, Dwayne Harty, Robyn Donison and I returned to the area hoping to see the ibis and photograph it. We found the bird in the same slough and good views were obtained from about 250 yards with the aid of a 20- to 60power telescope. It was in full breeding plumage with the "white face" clearly evident, as well as the red eyes and facial markings. It appeared wary at first and flew a short distance on our arrival but later I was able to stalk it on foot close enough to obtain some photos.

On June 1, Frank Brazier and Bob Kreba studied the ibis in the same slough. It was not found when Luterback checked the area again on June 20 .
W. Earl Godfrey in "Birds of Canada" 1966 gave the range of the White-faced Ibis as follows: "From central California, eastern Oregon, Colorado, Nebraska, southwestern Louisiana, and Florida (locally) south to Argentina and Chile. Status in Canada: Casual straggler to British Columbia."

There was evidence that the species may have bred at Pakowki Lake in southeastern Alberta and at Bowdoin National Wildlife Refuge, Montana, in 1975.21

Bob Luterbach, Bob Kreba and I observed an ibis at the Benton Lake National Wildlife Refuge, near Great Falls, Montana, on July 2, 1976.

It would appear that the Whitefaced Ibis has extended its range northwards in recent years.

'SERR, ESTHER. 1975 Northern Great Plains, In The nesting Season June 1 - July 31, 1975. American Birds 29:995-999.

'SMITH, W. W., and C. A. WALLIS. 1976 Preliminary investigation of the birds of Pakowki Lake, Alberta. Blue Jay 34: 168-171. 